\title{
Evaluation of Spirulina (Spirulina platensis) wastes and live housefly (Musca domestica) larvae as dietary protein sources in diets of Oreochromis niloticus (Linnaeus 1758) fingerlings
}

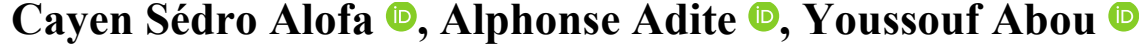

Cite this article as:

Alofa, C.S., Adite A., Abou, Y. (2020). Evaluation of Spirulina (Spirulina platensis) wastes and live housefly (Musca domestica) larvae as dietary protein sources in diets of Oreochromis niloticus (Linnaeus 1758) fingerlings. Aquatic Research, 3(1), 24-35. https://doi.org/10.3153/AR20003

Laboratory of Ecology and Aquatics Ecosystems Management, Department of Zoology, Faculty of Sciences and Technics, University of

Abomey-Calavi, 01 BP 526 Cotonou, Benin

ORCID IDs of the author(s): C.S.A. 0000-0002-3412-3362

A.A. 0000-0002-2255-4464 Y.A. 0000-0002-8273-0036

Submitted: 25.10 .2019

Revision requested: 25.11 .2019

Last revision received: 15.12 .2019

Accepted: 15.12 .2019

Published online: 18.12.2019

Correspondence:

Cayen Sédro ALOFA

E-mail: alofacayen@gmail.com

\begin{abstract}
This study was designed to evaluate spirulina wastes and live housefly maggot as partial replacement for fishmeal in the diets of Nile Tilapia. Four isonitrogenous (35\%) and isocaloric (17-18 KJ.g $\left.{ }^{-1}\right)$ diets were evaluated: commercial diet Skretting SK, control diet CD (30\% fishmeal), and two others diets (SW and LM), corresponding to spirulina wastes and live housefly maggot inclusion respectively. Diets were hand-fed thrice daily to triplicate groups of fish to apparent satiation. After 12 weeks, the final weight and feed intake of fish fed diet CD and SK did not differ from those fed diets LM, but were higher than those fed SW diet $(p<0.05)$. However, inclusion of SW had no effect on feed utilization. No significant differences were found in survival, feed conversion ratio, protein efficiency ratio and condition factor among the treatments $(p>0.05)$. Whole-body protein contents were similar in all groups, whereas the lipid content was lower in SW group. It was concluded that a $62.56 \%$ fishmeal protein could be replaced by live maggot in the diet of Nile Tilapia without negative effects on growth performances and quality of fish produced.
\end{abstract}

Keywords: Spirulina wastes, Live maggots, Fishmeal, Growth, Nile tilapia

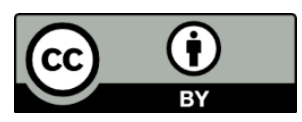

(C)Copyright 2020 by ScientificWebJournals Available online at

$\underline{\text { http://aquatres.scientificwebjournals.com }}$ 


\section{Introduction}

Nowadays, aquaculture industry provides half of all fish for human consumption (FAO, 2016; Esmaeili et al., 2017). The expansion of this sector highly depends on industrially feeds (Tacon et al., 2006). This feed rely on fishmeal as a major source of protein, highly digestible essential amino acids and fatty acids (Cho and Kim, 2011). The use of fishmeal as a major protein source in fish feed has heavily pooled to increased demand and prices for this raw material. Finding a suitable substitute for fishmeal is one means to reduce total operating costs in aquaculture industry (Webster et al., 1997). Furthermore, plants protein do not constitute the utmost alternatives to fishmeal, and for this reason, the need to find new aquafeed ingredients presently remains a real challenge (Vizcaino et al., 2014).

In plant protein, microalgae has received significant consideration in fish feed manufacturing because of its high protein content, vitamins, polysaccharides, polyunsaturated fatty acids, microelements and antioxidant pigments (Hemaiswarya et al., 2011). Among the microalgae, Spirulina, which is a quite promising source of protein, is widely distributed and easily cultured in tank (Huo et al., 2012). In recent years, Spirulina meal has been successfully used as a feed additive (Silva-Neto et al., 2012) or alternative protein source (Teimouri et al., 2013; Velasquez et al., 2016) in aquafeeds to improve weight gain and carcass quality of fish. Because Spirulina platensis is one of the most habitually used dietary complements in human comsumption and many animal species, including fish. Its wastes, which is rich in protein, can be used as dietary protein source in Nile Tilapia diets. Abdelkhalek et al. (2015) indicated that Spirulina platensis supplementation in O. niloticus diets, could minimize deltamethrin (DLM) induced toxic effects by its mighty antioxidant activity. It is also a protective agent anti hepatotoxicity in freshwater catfish Clarias batrachus (Ahmad Dar et al., 2014). Inclusion of Spirulina maxima in diets for juvenile common carp Cyprinus carpio results in increased growth rate (Ramakrishnan et al., 2008).

At the present time, some plant protein sources, such as Azolla meal (Abou et al., 2007ab) ; cereal grain products and by-products (Guimarães et al., 2008), corn co-products (Herath et al., 2016), Jatropha curcas kernel meal (Krome et al., 2016) ; soybean meal (Al-Feky et al., 2016), have been used to partially or totally replacement fishmeal in diets of Nile Tilapia. However, greatest in amount plant-based feedstuffs have a large variety of anti-nutritional factors, which may decrease fish growth performance. To ensure high production and fast growth at least cost, a well-balanced formulated feed is necessary for profitable tilapia farming. In some countries, different by-products such as chicken viscera are frequently left to rot in environment. This by-product pose pollution and health problems to local communities. Moreover, the poultry production industry generates large amounts of by-products (Adler et al., 2014). However, there is currently poorly used as a protein source in aquafeeds. We can used this by-products to produce enriched housefly maggot.

The housefly (Musca domestica) (Diptera : Muscidae) can feed on a wide variety of spoiled organic matter, such as distillers grains, fish offal, food and vegetable waste and animal manure (Salomone et al., 2017). In addition, insect's larvae have the potential to convert the animal manure into precious biomass. For instance, blacks soldiers flies has been assessing as a prospective animal to use in bioconversion of manure to reduce waste remnant. They can reduce nitrogen waste by $75 \%$ and mitigate mass by $50 \%$ in poultry process (Newton et al., 2005). As mentioned above, chicken viscera poses a potential feedstock for housefly larvae. Housefly maggots are rich in proteins and lipids, and research on their use as meals has given good results for several of the aquaculture species tested (Ogunji et al., 2008; Lin and Mui, 2016). Although, several studies on maggot meal have been published (Ogunji et al., 2008 ; Wang et al., 2017), little reports have been performed about the use of live housefly ; this is case of African catfish (Emeka and Oscar, 2016) and no reports in Nile tilapia, the most important farmed tilapia species around the world. Thus, use of live housefly maggot for $O$. niloticus diets as fishmeal replacement is warranted. For this purpose, our study was aimed to assess a animal protein source (live housefly Musca domestica maggot) and single-cell protein spirulina Spirulina platensis wastes, tested separately, in practical diets for Nile tilapia substituting the fishmeal component in formulated experimental diets for this species.

\section{Material and Methods}

\section{Fish and Experimental Procedures}

Monosex male Nile Tilapia fingerling (O. niloticus) were obtained from Private fish farming 'Dieu Exauce' located in Tori Avamey at Tori-Bossito (Benin). Tilapia were transported in oxygenated plastic bags to the Experimental Fish Farming Unit of Laboratory of Ecology of Aquatics Ecosystems of the University of Abomey Calavi, Benin, where the experiment was realized. Initially, 350 fish were stocked in $1 \mathrm{~m}^{3}$ circular concrete tank and maintained during one week before start the feeding trial. During this time, they were fed with a mixture of experimental diets. A total of 600 fish with an average weight $8.65 \pm 0.5 \mathrm{~g}$ were equally distributed into 
four experimental triplicate groups and stocked into 12 circular concrete tanks (diameter : $120 \mathrm{~cm}$ with capacity of 1000 1). Before the beginning of the experiment, fish were starved for 24 hours. The fish were fed their assigned diets thrice a day $(09: 00 ; 13: 00$ and $17: 00 \mathrm{~h})$ to apparent satiation and the quantity of feed consumed recorded for each tank. A outdoor recirculation rearing system was used to conduct the experiment, with water flow set at $3 \mathrm{~L} \mathrm{~min}^{-1}$. Fish were weighed collectively at the beginning and fortnightly for each tank to determine gain in weight.

\section{Ingredients and Experimental Diet}

Housefly Musca domestica larvae produced from chicken viscera and spirulina Spirulina platensis wastes were used as a partial protein replacement of fishmeal in fish diets. Chicken viscera were collected from the poultry processing industry "Agrisatch" (Abomey-calavi, Benin), and incubated in an rectangular areas (measuring $3 \mathrm{~m} \times 2 \mathrm{~m}$ ) as a substrate for housefly larvae development. The substrate was watered twice daily with water to prevent drying and exposed for two days to let houseflies to spawn eggs on it. The substrate was covered and left among 3 to 5 days to enable maggot to be grown before harvesting. The harvested houseflies maggots were washed and pre-cooked in warm water at $85^{\circ} \mathrm{C}$ during 15 minutes in order to prevent disease pathogens infection, before being incorporated in the practical diet.

Sardinella $s p$ fishmeal was used in the formulation of experimental diets. This ingredient is purchased at the Dantokpa market and sun-dried for three days before being transformed into meal. Blood meal was obtained following the procedures described by Alofa et al. (2016). The rest of the ingredients for the diets such as soybean meal, cottonseed meal, palm oil and salt were obtained at local market. Dry matter, crude protein, ether extracts and ash of housefly maggot and spirulina wastes used in this experiment were analysed (Table 1) to assist in experimental diet formulation (Table 2). The costs of ingredients used in the formulation of practical diets are given in Table 3.

After 2 week of acclimatization, the fish were fed one of the four experimental diets ( 3 tanks per treatment) for 86 days : one commercial diet Skretting SK, one control diet CD (no housefly maggot and spirulina wastes), and diets to which 15 $\%$ and $25 \%$ of spirulina wastes and live housefly maggot were added respectively. Diets were denoted LM (250 g. Kg${ }^{1}$ live maggot ; 935 g.Kg basis live weight) ; SW (150g. $\mathrm{Kg}^{-1}$ Spirulina wastes). Spirulina wastes was supplied by Spirulina Production Unit of the Regional Institute for Development and Health (SPU/RIDH), located in Pahou (Ouidah, Benin). These wastes were generated from the production and packaging process of spirulina.

\section{Preparation}

Diets were formulated to contain $35 \%$ crude protein and $17-$

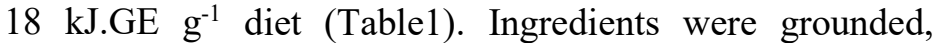
weighed, and mixed. Mixtures were then pelleted using a meat grinder to form pellets. The pellets were sun-dried and stored in plastic bags at $-4{ }^{\circ} \mathrm{C}$ until use. For the preparation of diet containing live maggot, this by-product was precooked ground with food grinder (Binatone BLG 450) and blended at least to make a paste before being to added to others ingredients.

\section{Sampling and Water Quality Monitoring}

Twenty fish were randomly selected to determine initial whole fish body nutrient composition and stored at $-20^{\circ} \mathrm{C}$ until analysis. Biomass of each tank was recorded at the beginning and end of this trial. Ten fish per tank were randomly chosen $(n=30$ per treatment). Fish weight, total length, were recorded to calculate condition factor $(\mathrm{CF})$.

Water parameters such as hydrogen potential $(\mathrm{pH})$, temperature $\left({ }^{\circ} \mathrm{C}\right)$, dissolved oxygen $(\mathrm{mg} / \mathrm{L})$, salinity $(p s u)$, conductivity $(\mu \mathrm{S} / \mathrm{cm})$ and total dissolved solid (TDS $\mathrm{mg} / \mathrm{L})$ were measured weekly at a deep of $10 \mathrm{~cm}$ for each reared tank with a multiparameter probe (Hanna HI 9829 v1.04, Hanna Instruments Ltd., USA). Nitrite and ammonium were determined by cadmium reduction and phenate methods respectively using spectrophotometer Hach DR6000. These parameters were checked three times fortnightly.

\section{Calculations}

To show the effect of spirulina wastes and live housefly larvae inclusion on growth performance and nutritional indices, the next parameters were determined as average of the triplicates by the formulas given.

Survival rate $\left(\right.$ SR, \%) $=\frac{\text { final amount of fish }}{\text { initial amount of fish }} \times 100$

Weight gain rate (WGR, \%)
$=\frac{(\text { final body weight }- \text { initial body weight })}{\text { initial amount of fish }} \times 100$

Specific growth rate (SGR, \%)

$=\frac{\text { Ln }(\text { final weight gain })-\ln (\text { initial weight })}{\text { rearing period }} \times 100$ 
Feed intake (FI, g/fish)

$=\frac{\text { total amount of the dry feed consumed }}{\text { fish numbers X days }} \times 100$

Protein efficiency ratio (PER)

body weight gain

$=\overline{\text { total feed consumed protein content in diets }}$

Feed Conversion Ratio (FCR)

$=\frac{\text { total dry feed consumed }}{\text { body weight gain }}$
Condition factor $(\mathbf{C F})=\frac{\text { final body weight }(\mathrm{g})}{\text { body length }(\mathrm{cm}) 3} X 100$

Yield $(\mathrm{Kg} / \mathrm{m3})$

$=\frac{\text { final biomass per tank }(\mathrm{g})-\text { initial bimass per tank }(\mathrm{g})}{\text { water volume }(1 \mathrm{~m} 3)}$

Production $(\mathrm{Kg} / \mathrm{m} 3 /$ year $)=\frac{\text { Yield } \times 365}{\text { rearing period }}$

\section{Economic conversion ratio (ECR)}

$=$ Cost of diet $\mathrm{x}$ Feed Conversion Ratio (FCR)

Profit index $(\mathbf{P I})=\frac{\text { Price of fish produced }}{\text { Price of feed consumed }}$

Table 1. Formulation and proximate composition of experimental diets fed monosex Nile Tilapia fingerlings during 12 week

\begin{tabular}{|c|c|c|c|c|}
\hline & \multicolumn{4}{|c|}{ Dietary treatments } \\
\hline & $\mathbf{S K}^{1}$ & CD & SW & LM \\
\hline \multicolumn{5}{|l|}{ Ingrédients $\left({\left.\mathrm{g} 100 \mathrm{~g}^{-1}\right)}^{-1}\right.$} \\
\hline Sardinella sp. fishmeal & & 30 & 10 & 10 \\
\hline Spirulina wastes & & - & 15 & - \\
\hline Live housefly maggot & & - & - & 25 \\
\hline Blood meal & & 7 & 7 & 7 \\
\hline Corn bran & & 36 & 21 & 25 \\
\hline Soybean meal & & 14 & 25 & 22 \\
\hline Cottonseed meal & & 10 & 19 & 11 \\
\hline Palm oil & & 2 & 2 & 2 \\
\hline Salt (NaCl) & & 1 & 1 & 1 \\
\hline \multicolumn{5}{|l|}{ Proximate composition } \\
\hline Dry matter (\%) & & 90.16 & 90.31 & 90.24 \\
\hline Crude protein (\% DM) & & 35.32 & 35.08 & 35.13 \\
\hline Crude lipid (\% DM) & & 8.15 & 9.19 & 11.88 \\
\hline NFE $^{2}$ & & 36.42 & 34.15 & 31.95 \\
\hline Ash (\% DM) & & 7.95 & 7.21 & 6.45 \\
\hline $\operatorname{Gross} \operatorname{energy}^{3}\left(\mathrm{~kJ} \mathrm{~g}^{-1}\right)$ & & 17.85 & 17.82 & 18.58 \\
\hline Diet cost $\left(\mathrm{USS} . \mathrm{Kg}^{-1}\right)^{4}$ & 1.87 & 1.00 & 0.69 & 0.67 \\
\hline
\end{tabular}

1. Proximate composition : Crude protein : 35\% ; Crude fat : 9\% ; Fibre : $3.4 \%$; Ash : 6.5\%, Calcium : 1\% ; Phosphore : 1\%, Lysine : $1.5 \%$; Methionine : $0.5 \%$; CuSO4 : $5 \mathrm{mg} / \mathrm{Kg}$

2. Nitrogen-free-extract $(\mathrm{NFE})=100-(\%$ moisture $+\%$ crude protein $+\%$ crude lipid $+\%$ ash $+\%$ crude fibre $)$.

3. Gross energy (GE) was calculated using the factors of $23.7 \mathrm{KJg}^{-1}, 39.5 \mathrm{KJg}^{-1}$ and $17.2 \mathrm{KJg}^{-1}$ protein, lipids and carbohydrates respectively (Guillaume et al., 1999).

4. Prices in US\$, 1 US\$=586.69 FCA at present. Including labour and processing 
Table 2. Analysed nutrient composition (as \% dry matter) of feeds ingredients

\begin{tabular}{lccccc}
\hline Ingredients & Dry matter & Crude protein & Crude lipid & Ash & Crude fibre \\
\hline Fish meal & 92.0 & 66.0 & 7.88 & 15.77 & 1.0 \\
Spirulina wastes & 91.53 & 46.32 & 6.71 & 10 & 3.2 \\
Maggot meal & 91.7 & 48.8 & 20.1 & 6.25 & 6.1 \\
Soybean oilcake & 94.8 & 30 & 13.2 & 3.7 & 6.0 \\
Cottonseed oilcake & 90.0 & 40.5 & 7.0 & 8.0 & 14.0 \\
Blood meal & 90.9 & 71.9 & 1.7 & 6.4 & 1.6 \\
Maize bran & 91.4 & 6.2 & 3.1 & 1.4 & 12.3 \\
\hline
\end{tabular}

\section{Proximate Analysis}

Dry matter, crude protein, crude lipid, and ash in feed ingredients and fish (Table 1) were determined according to standard procedures of Association of Official Analytical Chemists, AOAC (Horwitz and Latimer, 2005). Dry matter was determined by drying samples in an oven (Memmert UN160 Plus) at $105^{\circ} \mathrm{C}$ for $24 \mathrm{hr}$. Crude protein was calculated from the nitrogen content $(\mathrm{N} \times 6.25)$ using the Kjeldahl method. Samples were first acid-digested. Crude lipid content in samples was determined by chloroform-methanol method (Folch et al., 1957), while crude ash content was determined by incineration samples at $500^{\circ} \mathrm{C}$ for $12 \mathrm{~h}$ and weighing the residual ash. All analysis was performed in triplicate.

\section{Statistical Analysis}

Data were expressed as the mean \pm SEM. of triplicate samples. All statistical analyses were conducted using Microsoft Excel and Statistical Package for Social Sciences (SPSS IBM version 20.0 for windows v8.1, Chicago, Illinois, USA). Prior analysis, homogeneity of variance was determined using the Hartley statistical test after log transforming (Dagnelie, 1975). Differences in the mean levels of the parameters between the dietary treatments were determined using one way analysis of variance ANOVA followed by Tukey's test of multiple comparison. The differences were considered significant when $\mathrm{p}$-value were $<0.05$.

\section{Results and Discussion}

The search for sustainable ingredients to replace fishmeal has been a real challenge for the Tilapia industry. At fishmeal substitution experiment, the quality of FM is of great importance on how tested products perform as FM substitutes (Biswas et al., 2017). In this experiment, a high quality of FM produced from Sardinella spp with protein contents approximately $660 \mathrm{~g} \mathrm{~kg}^{-1}$ was used. Housefly larvae are converters of organic waste into expendable biomass of which the composition may attribute on the substrate. In this experiment, larvae were grown on chicken viscera.
The effects of SW and LM inclusion on tilapia performance, nutrient utilization and production are presented in Table 5. Although there was little variation in lipid contents as indicated in Table 1, all experimental diets were isocaloric and isonitrogeneous. Growth parameters were poor in fish fed SW diet and similar $(p<0.05)$ in those fed CD, SK and LM diets (Figure 1). There were no significant differences $(p>$ $0.05)$ in final weight $(80.96-88.54 \mathrm{~g})$, DWG $(0.86-0.95 \mathrm{~g}$. days $\left.^{-1}\right)$, SGR $\left(2.68-2.77 \%\right.$ days $\left.^{-1}\right)$ and annual production $\left(13.88-16.03 \mathrm{Kg} / \mathrm{m}^{3} /\right.$ year) of Nile tilapia fed with control diets and LM diet (Table 5). These findings indicated that the growth performance and feed efficiency of $O$. niloticus juveniles fed live housefly larvae were not significantly affected by the replacement of fishmeal up to $66 \%$, showing that LM protein can be used to partially substitute FM in a practical diet of Nile tilapia. This is in agreement with the findings of Oyelese (2007) and Ogunji et al. (2008) that used it as partial FM substitute without affecting growth and feed utilization in Tilapia and catfish juveniles. The current study is in agreement with the earlier reported Tilapia studies and exemplifies the possible use of live housefly maggot as a partial substitute for FM in O. niloticus diets. Studies evaluating live housefly larvae in fish diets are highly few, but rising. Results of the current study in Nile Tilapia are similar to several studies in Teleost. In rainbow trout (Oncohynchus mykiss) for example, fish fed a diet with 18 up to $36 \%$ maggot meal (MM) produced from cow manures and fish offal had similar final average weight and weight gain as fish fed a control diet, whereas fish fed a diet containing 16 up to $33 \%$ MM produced from cow manures only had significantly reduced growth parameters (Sealey et al., 2011). This may be presumed that the nutrient content of fly larvae largely depends on their diet (Spranghers et al., 2017). In the present experiment, specific growth rate recorded in all traitment were comparatively higher than those of the anterior study (Wang et al., 2017) in which the SGR of Nile tilapia (initial weight : $68.89 \mathrm{~g}$ ) fed housefly MM were ranged from 1.12 to $1.62 \%$ per day. This difference might be due to the fish sizes or further rearing conditions. 


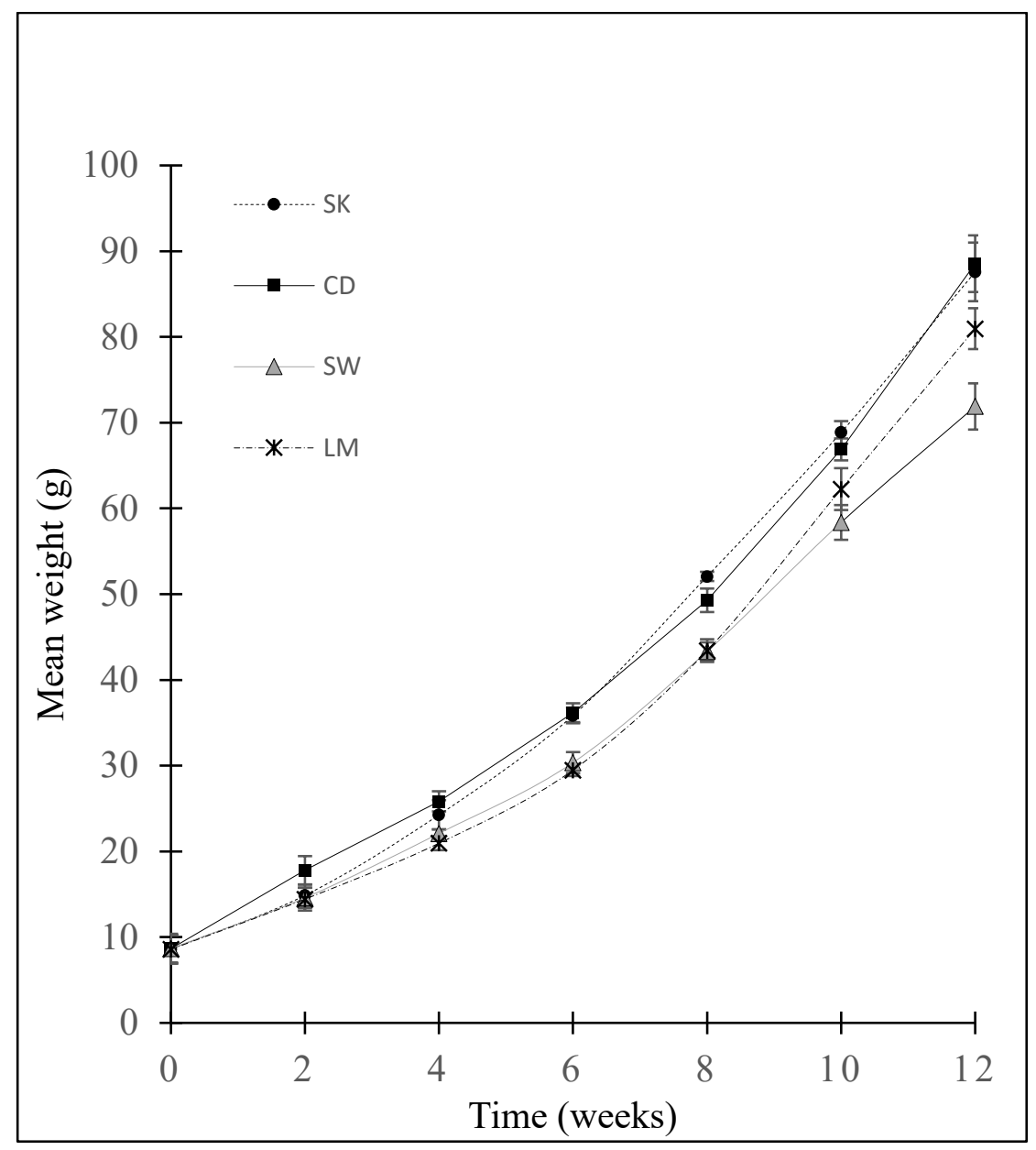

Figure 1. Mean weight (g) evolution of juvenile Nile Tilapia Oreochromis niloticus fed the commercial tilapia diet Skretting SK, the experimental diets containing Sardinella sp. fishmeal CD, Spirulina wastes SW and live housefly maggot LM during 12 weeks.

Table 3. Cost of ingredients used in formulating the diets

\begin{tabular}{ll}
\hline Ingredients & Price $\left(\mathbf{U S \$ . K \mathbf { K } ^ { - 1 }}\right)$ \\
\hline Sardinella $\boldsymbol{s p}$ fishmeal & 2.24 \\
Soybean meal & 0.67 \\
Cottonseed meal & 0.33 \\
Blood meal & 0.22 \\
Spirulina wastes meal & 0.43 \\
Housefly maggot meal & 0.44 \\
Corn bran & 0.26 \\
Palm oil & 1.38 \\
Salt $(\mathbf{N a C l})$ & 0.43 \\
\hline
\end{tabular}


Table 4. Water quality parameters in $O$. niloticus rearing tanks during the experimental period

\begin{tabular}{|c|c|c|c|c|}
\hline Parameters & SK & CD & SW & LM \\
\hline pH & $6.78 \pm 0.29$ & $6.81 \pm 0.29$ & $6.85 \pm 0.33$ & $6.83 \pm 0.30$ \\
\hline Temperature $\left({ }^{\circ} \mathrm{C}\right)$ & $29.88 \pm 0.68$ & $30.08 \pm 0.72$ & $29.88 \pm 0.78$ & $30.27 \pm 1.47$ \\
\hline Dissolved oxygen $\left(\mathrm{mg} \mathrm{L}^{-1}\right)$ & $3.12 \pm 0.56$ & $3.17 \pm 0.57$ & $3.15 \pm 0.58$ & $3.08 \pm 0.31$ \\
\hline Conductivity $(\mu \mathrm{S} / \mathrm{cm})$ & $179.7 \pm 84.1$ & $185.1 \pm 86.9$ & $181.8 \pm 88.0$ & $183.0 \pm 82.5$ \\
\hline TDS $\left(m g . L^{-1}\right)$ & $93.06 \pm 45.56$ & $94.63 \pm 45.22$ & $93.35 \pm 45.67$ & $93.31 \pm 42.29$ \\
\hline Salinity (psu) & $0.07 \pm 0.04$ & $0.08 \pm 0.04$ & $0.08 \pm 0.04$ & $0.08 \pm 0.04$ \\
\hline Nitrate (mg. $\left.L^{-1}\right)$ & $2.23 \pm 0.38$ & $2.33 \pm 0.25$ & $2.27 \pm 0.15$ & $2.73 \pm 0.35$ \\
\hline Nitrite (mg. $\left.\mathbf{L}^{-1}\right)$ & $0.04 \pm 0.00$ & $0.03 \pm 0.01$ & $0.03 \pm 0.01$ & $0.03 \pm 0.01$ \\
\hline
\end{tabular}

Data are expressed as means \pm SE $(n=3)$

SK: Skretting, CD: control diet, SW: spirulina wastes diet, LM: live housefly maggot diet

Table 5. Growth performance, feed efficiency and annual production of Oreochromis niloticus fed the experimental diets for 12 weeks.

\begin{tabular}{|c|c|c|c|c|}
\hline Parameters & SK & CD & SW & $\mathbf{L M}$ \\
\hline Initial weight (g) & $8.60 \pm 0.10$ & $8.66 \pm 0.14$ & $8.68 \pm 0.14$ & $8.53 \pm 0.03$ \\
\hline Final weight (g) & $87.59 \pm 3.42^{\mathrm{a}}$ & $88.54 \pm 3.30^{\mathrm{a}}$ & $71.89 \pm 2.70^{\mathrm{b}}$ & $80.96 \pm 2.38^{\mathrm{a}}$ \\
\hline Feed intake ( $\left.\mathrm{g} \mathrm{fish}^{-1}\right)$ & $94.93 \pm 3.20^{\mathrm{ab}}$ & $104.84 \pm 3.33^{\mathrm{a}}$ & $83.73 \pm 3.17^{\mathrm{c}}$ & $94.81 \pm 4.54^{\mathrm{bc}}$ \\
\hline Survival rate (\%) & $96.00 \pm 2.00$ & $94.00 \pm 2.00$ & $94.00 \pm 2.00$ & $91.33 \pm 2.31$ \\
\hline Weight gain (\%) & $918.8 \pm 41.8^{\mathrm{a}}$ & $923.4 \pm 54.7^{\mathrm{a}}$ & $728.8 \pm 31.2^{\mathrm{b}}$ & $848.8 \pm 30.8^{\mathrm{a}}$ \\
\hline Daily weight gain (g. days ${ }^{-1}$ ) & $0.94 \pm 0.04^{\mathrm{a}}$ & $0.95 \pm 0.04^{\mathrm{a}}$ & $0.75 \pm 0.03^{b}$ & $0.86 \pm 0.03^{\mathrm{a}}$ \\
\hline Specific growth rate $\left(\%\right.$ days $\left.^{-1}\right)$ & $2.76 \pm 0.05^{\mathrm{a}}$ & $2.77 \pm 0.06^{\mathrm{a}}$ & $2.52 \pm 0.04^{\mathrm{b}}$ & $2.68 \pm 0.04^{\mathrm{a}}$ \\
\hline Feed conversion ratio & $1.21 \pm 0.09$ & $1.32 \pm 0.02$ & $1.34 \pm 0.02$ & $1.32 \pm 0.05$ \\
\hline Protein efficiency ratio & $2.37 \pm 0.18$ & $2.16 \pm 0.04$ & $2.14 \pm 0.03$ & $2.16 \pm 0.09$ \\
\hline Condition factor & $1.92 \pm 0.09$ & $1.89 \pm 0.12$ & $1.80 \pm 0.02$ & $1.80 \pm 0.07$ \\
\hline Yield $\left(\mathrm{Kg} / \mathrm{m}^{3}\right)$ & $3.78 \pm 0.25^{\mathrm{a}}$ & $3.73 \pm 0.25^{\mathrm{a}}$ & $2.94 \pm 0.07^{\mathrm{b}}$ & $3.27 \pm 0.17^{\mathrm{ab}}$ \\
\hline Production $\left(\mathrm{Kg} / \mathrm{m}^{3} /\right.$ year) & $16.03 \pm 1.06^{\mathrm{a}}$ & $15.84 \pm 1.06^{\mathrm{a}}$ & $12.49 \pm 0.30^{\mathrm{b}}$ & $13.88 \pm 0.71^{\mathrm{ab}}$ \\
\hline
\end{tabular}

Values in a row with different letters are significantly different $(p<0.05$, Tukey's test).

SK: Skretting, CD: control diet, SW: spirulina wastes diet, LM: live housefly maggot diet

Water quality parameters values during the feeding trial were exposed in Table 4 . The water temperature ranged from 29.88 to $30.27^{\circ} \mathrm{C}$, pH from 6.78 to 6.85 , dissolved oxygren from 3.08 to $3.17 \mathrm{mg} . \mathrm{L}^{-1}$, salinity from 0.07 to $0.08 \mathrm{mg} . \mathrm{L}^{-1}$, nitrate from 2.23 to $2.73 \mathrm{mg} . \mathrm{L}^{-1}$ and nitrite from 0.03 to $0.04 \mathrm{mg}$. $\mathrm{L}^{-}$ ${ }^{1}$. No significant differences were observed in these parameters $(p>0.05)$. These parameters recorded were optimal for the monosex male Nile Tilapia used in the experiment, because the optimal temperature for this species must be in a range between 12 and $16^{\circ} \mathrm{C}$ and the dissolved oxygen content should not lower than $3 \mathrm{mg}$. L ${ }^{-1}$ (Bhujel, 2000). Thereby, experimental diet did not affect significantly the $\mathrm{pH}$ of the dietary traitment, these remarks were in contrariness of the results noted from Promya and Chitmanat (2011) that recorded higher values of $\mathrm{pH}$ in tank with fish fed with a diet including algae. Survival rate of experimental fish were not affected by the presence of spirulina wastes in the diet, ranging from 91 to $96 \%$. Similar data were observed for several fish fed spirulina meal diets (Sirakov et al., 2012; Promya and Chitmanat, 2011).

On the other hand, spirulina contains a large amount in proteins essential, vitamins, minerals, amino acids and fatty acids, antioxidant pigments and has been identified as a feed ingredient for cichlids; it seems to be a hopeful dietary protein source (Guroy et al., 2012).

Feed intake had decreased $(\mathrm{p}<0.05)$ in fish fed SW diet $\left(83.73 \pm 3.17 \mathrm{~g}\right.$. fish $\left.^{-1}\right)$. In contrast, fish fed LM diet $(107.95$ $\pm 3.31 \mathrm{~g}$. fish ${ }^{-1}$ ) had similar FI with those fed control diet SK 
and $\mathrm{CD}\left(94.93 \pm 3.20\right.$ and $104.84 \pm 3.33 \mathrm{~g} \mathrm{fish}^{-1}$ respectively). Our results were in contrast of the data received from Guroy et al. (2012), who showed that Spirulina meal has the potential to enhance the growth, reproductive performance and coloration on yellow tail cichlid Pseudotropheus acei. Several studies have shown that dietary Spirulina can affect the growth performance of diverse fish species. For example, it has previously been reported that 20 up to $40 \%$ of FM can be substitute with spirulina meal without negative effect on the growth performance of hybrid red tilapia (Ungsethaphand et al., 2010). Moreover, Guroy et al. (2012) reported that spirulina meal could be replaced fishmeal up to $10 \%$ in yellow tail cichlid diets without any adverse effects on growth, reproductive performance or coloration. Likewise, it has been reported that that dietary inclusion of $8 \%$ Spirulina significantly enhanced growth performance of the ornamental red swordtail Xiphophorus helleri (James et al.,2006). Furthermore, according to Yeganeh et al. (2015), it's well known that the increase in HDL-cholesterol with spirulina inclusion suggests that Spirulina may improve the cardiovascular activity in rainbow trout (Oncorhynchus mykiss).

No significant differences in feed conversion ratio (1.21 $1.34)$, protein efficiency ratio $(2.14-2.37)$ and condition factor $(1.80-1.92)$ were observed among these groups. However, fish fed SW diet showed significantly lower final mean body weight compared with other group being represented the lower value $(p<0.05$, Table 5$)$. The poor growth performance in fish fed SW diet might be due to the lower digestibility of microalgae, due to the presence of a cellular wall, as suggested Le Vay et al. (2001). It has been demonstrated in most studies that low growth rates of fish fed with plant protein-based diets were attributed with poor feed intake that was strongly influenced by the palatability of diets (Kader and Koshio, 2012). In the present study, FI was significantly decreased in fish fed SW diet which indicated that SW protein sources can negatively affect palatability. FI is highly influenced by the palatability of diets; it's one of the most important factor coupled with the efficiency on the utilization of protein sources in fish (Kader et al., 2012). Plant protein are successfully used in feed formulations for rearing tilapia species because Tilapias have herbivorous or omnivorous feeding habits and lower level of the aquatic food chain. Likewise, growth performances obtained with the spirulina wastes protein in this study was lower than previously reported for others aquatic species of similar weight fed with spirulina such as the yellow tail cichlid Pseudotropheus acei (Guroy et al., 2012), Litopenaeus schmitti larvae (Jaime-Ceballos et al., 2006), the sturgeon Acipenser baeri (Palmegiano et al., 2005) and $O$. mossambicus X $O$. niloticus (Ungsethaphand et al., 2010). It has been demonstrated that high quality spirulina meal was an adequate and nutritious protein source that increased growth in several species such as Common carp $C y$ prinus carpio (Ramakrishnan et al., 2008); sturgeon Acipenser baeri (Palmegiano et al., 2005). However, Spirulina meal has high protein content (i.e. $66.9 \%$ ) compared with spirulina wastes ( $46.32 \%$ crude protein) used in the present study. Therefore, the adverse effect following SW inclusion might be also due to the lower protein content observed in fish fed SW diet.

In our study, PER was more favorable in spirulina wastes based diet than in the control diet SK and CD. A similar observation was made using Spirulina platensis at different levels in sturgeon (Acipenser baeri) (Palmegiano et al., 2005). However, The FCR and PER in O. niloticus fed Spirulina wastes based diets were similar than those of the control diets CD and SK. The results of this work are similar to those found by Teimouri et al. (2013) in which rainbow trout (Oncorhynchus mykiss) fingerlings fed with control diet, 7.5 and $10 \% \mathrm{~S}$. platensis inclusion diets as feed supplement, showed comparable feed conversion ratio. Furthermore, the cellular structure (mucopolymer murein) of Spirulina alga is readily digestible and does not contain cellulose (Beresto, 2001). Wherefore, significant decrease on growth performance in fish fed SW diet may be associated by the lower feed intake observed in these fishes.

The variation in the final whole-body proximate composition is reported in Table 6. Except dry matter and crude protein content, all whole body compositions were significantly affected by dietary protein source $(p<0.05)$. Crude lipid content in fish fed with SW diet were significantly lower than those in fish fed any other diets $(p<0.05)$. However, lipid contents was significantly higher in fish fed with LM diet, whereas ash content significantly decreased $(p<0.05)$, reflecting the lipid and ash contents of this protein source. The results of the economic analysis are shown in Table 7. As it can be seen, profit index significantly increased with fish fed both SW and LM diets whereas economic conversion ratio decreased significantly. Economic analysis shows that inclusion of both SW and LM in the diet improves profitability. 
Table 6. Proximate composition (\%) of whole body of Oreochromis niloticus fed the experimental diets: CD, diet containing fish meal; LM, diet containing live housefly maggot and SW, diet with spirulina wastes meal.

\begin{tabular}{lcccccc}
\hline Diets & Initial & SK & CD & SW & LM & p-values \\
\hline Dry matter & $89,82 \pm 0,12$ & $91,91 \pm 0,04$ & $90,50 \pm 0,47$ & $90,57 \pm 0,06$ & $91,45 \pm 1,46$ & 0,319 \\
Crude protein & $63,14 \pm 0,70$ & $61,40 \pm 0,44$ & $62,45 \pm 0,08$ & $60,26 \pm 1,37$ & $59,27 \pm 1,13$ & 0,090 \\
Crude lipid & $10,76 \pm 0,59$ & $32,59 \pm 1,86^{\mathrm{a}}$ & $33,56 \pm 1,66^{\mathrm{a}}$ & $26,15 \pm 0,38^{\mathrm{b}}$ & $35,77 \pm 0,59^{\mathrm{a}}$ & 0.007 \\
Ash & $16,52 \pm 81,19$ & $14,79 \pm 0,68^{\mathrm{ab}}$ & $17,43 \pm 2,37^{\mathrm{a}}$ & $15,29 \pm 0,17^{\mathrm{ab}}$ & $11.13 \pm 1.32^{\mathrm{b}}$ & 0,046 \\
\hline
\end{tabular}

Values in the same column with different superscripted small letters mean significant difference $(\mathrm{p}<0.05)$. Values show mean \pm standard error, $n=3$

Table 7. Summary of cost benefit analysis of Nile Tilapia fed the test diets

\begin{tabular}{|c|c|c|c|c|c|}
\hline Diets & SK & $\mathbf{C D}$ & SW & $\mathbf{L M}$ & \multirow{2}{*}{$\begin{array}{l}\text { Anova } \\
\text { p-values }\end{array}$} \\
\hline Parameters & & & & & \\
\hline Total feed used $\left(\mathrm{Kg} \mathrm{m}^{-3}\right)$ & $4.56 \pm 0.07^{\mathrm{ab}}$ & $4.93 \pm 0.26^{\mathrm{a}}$ & $3.93 \pm 0.12 \mathrm{c}$ & $4.33 \pm 0.32^{\mathrm{bc}}$ & 0.003 \\
\hline Cost of feeding (US\$. $\mathrm{m}^{-3}$ ) & $8.517 \pm 0.12^{\mathrm{a}}$ & $4.93 \pm 0.26^{\mathrm{b}}$ & $2.72 \pm 0.08^{c}$ & $2.90 \pm 0.21^{\mathrm{c}}$ & 0.000 \\
\hline Price of fish produced (US\$. $\mathrm{m}^{-3}$ ) & $9.78 \pm 0.65^{\mathrm{a}}$ & $9.66 \pm 0.65^{\mathrm{a}}$ & $7.62 \pm 0.18^{\mathrm{ab}}$ & $8.47 \pm 0.43^{b}$ & 0.003 \\
\hline Economic Conversion Ratio (US\$. $\mathbf{K g}^{-1}$ ) & $2.26 \pm 0.18^{\mathrm{a}}$ & $1.32 \pm 0.02^{\mathrm{b}}$ & $0.92 \pm 0.02^{\mathrm{c}}$ & $0.89 \pm 0.04^{\mathrm{c}}$ & 0.000 \\
\hline Profit Index & $1.15 \pm 0.09^{\mathrm{c}}$ & $1.96 \pm 0.03^{\mathrm{b}}$ & $2.81 \pm 0.05^{\mathrm{a}}$ & $2.92 \pm 0.12^{\mathrm{a}}$ & 0.000 \\
\hline
\end{tabular}

SK: Skretting, CD: control diet, SW: spirulina wastes diet, LM: live housefly maggot diet

\section{Conclusion}

In conclusion, the results clearly indicate that $O$. niloticus fed housefly larvae performed better than those fed spirulina wastes diet in terms of growth performance and feed utilization. Thus, $20 \%$ of FM could be saved by including $25 \%$ of live housefly larvae in the diet of Nile tilapia without any adverse effects on the growth performance and feed utilization. In this study there is no supplement aminoacids, feed stimulants or other marine fish products, which also have concern over their future availability like to FM. This ensures the plainness of diet formula for the successful production of this species in rural areas.

\section{Compliance with Ethical Standard}

Conflict of interests: The authors declare that for this article they have no actual, potential or perceived conflict of interests.

Ethics committee approval: This study was conducted in accordance with ethics committee procedures of animal experiments.

Financial disclosure: This research was funded by the Ministry of Higher Education and Scientific Research, Benin (Alofa C.S.'s Ph.D. thesis, University of Abomey-Calavi).

Acknowledgements: We are grateful to Mr. Appolinaire Effio, technician at the laboratory of zootechnics, Faculty of Agricultural Sciences, University of Abomey-Calavi for his assistance during the biochemical analysis. Mr Roger K. ADOUNKPE, Head of the Spirulina Production Unit of the Regional Center for Development and Health (Pahou, Benin) for the supply of spirulina by-products.

\section{References}

Abdelkhalek, N.K.M., Ghazy, EW., Abdel-Daim M.M. (2015). Pharmacodynamic interaction of Spirulina platensis and deltamethrin in freshwater fish Nile tilapia, Oreochromis niloticus: impact on lipid peroxidation and oxidative stress. Environmental Science and Pollution Research, 22(4), 30233031. https://doi.org/10.1007/s11356-014-3578-0

Abou, Y., Fiogbé, E.D., Micha, J.C. (2007a). A preliminary assessment of growth and production of Nile tilapia, Oreochromis niloticus $L$., fed azolla-based-diets in earthen ponds. Journal of Applied Aquaculture, 19(4), 55-69.

https://doi.org/10.1300/J028v19n04_03

Abou, Y., Fiogbé E.D., Micha, J.C. (2007b). Effects of stocking density on growth, yield and profitability of farming Nile tilapia, Oreochromis niloticus L., fed Azolla diet, in earthen ponds. Aquaculture Research, 38(6), 595-604. https://doi.org/10.1111/j.1365-2109.2007.01700.x 
Adler, S., Honkapää, K., Saarela, M., Slizyte, R., Sterten, H., Vikman, M., Løes, A.K. (2014). Utilisation of costreams in the Norwegian food processing industry: A multiple case study. Bioforsk Report, 9(82), 1-58.

Ahmad Dar, B., Khaliq, R., Jha, G.N., Kour, P., Qureshi, T.A. (2014). Protective effects of dietary spirulina against cadmium chloride exposed histoarchitectural changes in the liver of freshwater catfish Clarias batrachus (Linnaeus, 1758). Indian Journal of Fisheries, 61(3), 83-87.

Al-Feky, S.S.A., El-Sayed, A.F.M., Ezzat, A.A. (2016). Dietary taurine enhances growth and feed utilization in larval Nile tilapia (Oreochromis niloticus) fed soybean meal-based diets. Aquaculture Nutrition, 22(2), 457-464.

https://doi.org/10.1111/anu.12266

Alofa, C.S., Oke, V., Abou, Y. (2016). Effect of replacement of fish meal with broiler chicken viscera on growth, feed utilization and production of African catfish Clarias gariepinus (Burchell, 1822). International Journal of Fisheries and Aquatic Studies, 4(6), 182-186.

Beresto, V. (2001). Our experience in spirulina feeding to minks in the reproduction period. Scientifur, 25(1), 11-15.

Bhujel, R.C. (2000). A rewiew of strategies for the management of Nile tilapia (Oreochromis niloticus) broodfish in seed production systems, especially hapa-based systems. $A q$ uaculture, 181(1-2), 37-59.

https://doi.org/10.1016/S0044-8486(99)00217-3

Biswas, A., Araki, H., Sakata, T., Nakamori, T., Kato, K., Takii, K. (2017). Fish meal replacement by soy protein from soymilk in the diets of red sea bream (Pagrus major). Aquaculture Nutrition, 23(6), 1379-1389.

https://doi.org/10.1111/anu.12513

Cho, J.H., Kim, I.H. (2011). Fish meal nutritive value. Journal of Animal Physiology and Animal Nutrition, 95(6), 685692.

https://doi.org/10.1111/j.1439-0396.2010.01109.x

Dagnelie, L. (1975). Théories et méthodes statistiques. Presses Agronomiques de Gembloux, Belgique, 463p. ISBN10: 2870160070 .

Emeka, A.I., Oscar, E.V. (2016). Comparative Study of Growth Performance, Food Utilization and Survival of the
African Catfish Clarias gariepinus (Burchell, 1822) Fingerlings Fed Live Maggot (Musca domestica) and Coppens Commercial Feed. International Journal of Scientific Research in Science, Engineering and Technology, 2(2), 379386.

Esmaeili, M., Abedian Kenari, A., Rombenso, A.N. (2017). Effects of fish meal replacement with meat and bone meal using garlic (Allium sativum) powder on growth, feeding, digestive enzymes and apparent digestibility of nutrients and fatty acids in juvenile rainbow trout (Oncorhynchus mykiss Walbaum, 1792). Aquaculture Nutrition, 23(6), 12251234.

https://doi.org/10.1111/anu.12491

FAO, (2016). The state of world fisheries and aquaculture 2016. Contributing to food security and nutrition for all. Food and Agriculture Organization of the United Nations (FAO), Rome. ISBN 978-92-5-209185-1

Folch, J., Lees M., Sloane-Stanley, G.H. (1957). A simple method for the isolation and purification of total lipids from animal tissues. Journal of Biological Chemistry, 226, 497509.

Guimarães, I.G., Pezzato, L.E., Barros, M.M., Tachibana, L. (2008). Nutrient digestibility of cereal grain products and by-products in extruded diets for Nile tilapia. Journal of The World Aquaculture Society, 39(6), 781-789. https://doi.org/10.1111/j.1749-7345.2008.00214.x

Güroy, B., Sahin, I., Mantoglu, S., Kayalı, S. (2012). Spirulina as a natural carotenoid source on growth, pigmentation and reproductive performance of yellowtail cichlid Pseudotropheus acei. Aquaculture International, 20(5), 869-878. https://doi.org/10.1007/s10499-012-9512-x

Hemaiswarya, S., Raja, R., Ravi-Kumar, R., Ganesan, V., Anbazhagan, C. (2011). Microalgae: a sustainable feed source for aquaculture. World Journal of Microbiology and Biotechnology, 27(8), 1737-1746.

https://doi.org/10.1007/s11274-010-0632-Z

Herath, S.S., Haga, Y., Satoh, S. (2016). Potential use of corn co-products in fishmeal-free diets for juvenile Nile tilapia Oreochromis niloticus. Fisheries Science, 82(5), 811818.

https://doi.org/10.1007/s12562-016-1008-6

Horwitz, W., Latimer, GW. (2005). Official Methods of Analysis of AOAC International. 18th Edition, Association 
of Official Analytical Chemistry International, Maryland ISBN: $0935584757 \quad 9780935584752 \quad 093558482 X$ 9780935584820

Huo S., Wang, Z., Zhu, S., Zhou, W., Dong, R., Yuan, Z. (2012). Cultivation of Chlorella zofingiensis in bench-scale outdoor ponds by regulation of $\mathrm{pH}$ using dairy wastewater in winter, South China. Bioresource Technology, 121, 76-82. https://doi.org/10.1016/j.biortech.2012.07.012

James, R., Sampath, K., Thangarathinam, R., Vasudevan, I. (2006). Effect of dietary spirulina level on growth, fertility, coloration and leucocyte count in red swordtail, Xiphophorus helleri. Israeli Journal of Aquaculture - Bamidgeh, 58(8), 97-104.

Kader, M.A., Bulbul, M., Koshio, S., Ishikawa, M., Yokoyama, S., Nguyen, B.T., Komilus, C.F. (2012). Effect of complete replacement of fish meal by dehulled soybean meal with crude attractants supplementation in diets for red sea bream, Pagrus major. Aquaculture, 350-353, 109-116.

https://doi.org/10.1016/j.aquaculture.2012.04.009

Kader, M.A., Koshio, S. (2012). Effect of composite mixture of seafood by-products and soybean proteins in replacement of fishmeal on the performance of red sea bream, Pagrus major. Aquaculture, 368, 95-102.

https://doi.org/10.1016/j.aquaculture.2012.09.014

Krome, C., Jauncey, K., Focken, U. (2016). Jatropha curcas kernel meal as a replacement for fishmeal in practical Nile tilapia, Oreochromis niloticus feeds. AACL Bioflux, 9(3), 590-596.

Le Vay, L., Jones, D., Puello-Cruz, A., Sangha R., Ngamphonsai, C. (2001). Digestion in relation to feeding strategies exhibited by crustacean larvae. Comparative Biochemistry and Physiology Part A: Molecular \& Integrative Physiology, 128(3), 623-630.

https://doi.org/10.1016/S1095-6433(00)00339-1

Lin Y.H., Mui J.J. (2016). Evaluation of dietary inclusion of housefly maggot (Musca domestica) meal on growth, fillet composition and physiological responses for barramundi, Lates calcarifer. Aquaculture Research, 48, 2478-2485. https://doi.org/10.1111/are.13085

Newton, L., Sheppard, C., Watson, D.W., Burtle, G., Dove, R. (2005). Using the black soldier fly, Hermetia illu- cens, as a value-added tool for the management of swine manure. Anim. Poult. Waste Manag. Center, North Carolina, State Univ. Raleigh, NC 19p.

Ogunji, J.O., Kloas, W., Wirth, M., Schulz, C., Rennert, B. (2008). Housefly maggot meal (magmeal) as a protein source for Oreochromis niloticus (Linn.). Asian Fisheries Science, 21, 319-331.

Oyelese, O.A. (2007). Utilization of compounded ration and maggot in the diet of Clarias gariepinus. Research Journal of Applied Sciences, 2(3), 301-306.

Palmegiano, G.B., Agradi, E., Forneris, G., Gai, F., Gasco, L., Rigamonti, E., Sicuro, B., Zoccarato, I. (2005). Spirulina as a nutrient source in diets for growing sturgeon (Acipenser baeri). Aquaculture Research, 36, 188-195.

https://doi.org/10.1111/j.1365-2109.2005.01209.x

Promya, J., Chitmanat, C. (2011). The effects of Spirulina platensis and Cladophora algae on the growth performance, meat quality and immunity stimulating capacity of the African sharptooth catfish (Clarias gariepinus). International Journal of Agriculture and Biology, 13, 77-82.

Ramakrishnan, C.M., Haniffa, M.A., Manohar, M., Dhanaraj, M., Jesu Arockiaraj, A., Seetharaman, S., Arunsingh, S.V. (2008). Effects of probiotics and spirulina on survival and growth of juvenile common carp (Cyprinus carpio). The Israeli Journal of Aquaculture - Bamidgeh, 60(2), 128-133.

Salomone, R., Saija, G., Mondello, G., Giannetto, A., Fasulo, S., Savastano, D. (2017). Environmental impact of food waste bioconversion by insects: application of life cycle assessment to process using Hermetia illucens. Journal of Cleaner Production, 140(2), 890-905.

https://doi.org/10.1016/j.jclepro.2016.06.154

Sealey, W.M., Gaylord T.G., Barrows F.T., Tomberlin J.K., McGuire M.A., Ross C., St-Hilaire S. (2011). Sensory analysis of rainbow trout, Oncorhynchus mykiss, fed enriched black soldier fly prepupae, Hermetia illucens. Journal of the World Aquaculture Society, 42(1), 34-45.

https://doi.org/10.1111/j.1749-7345.2010.00441.x

Silva-Neto, J.F., Nunes, A.J.P., Sabry-Neto, H., Sa, M.V.C. (2012). Spirulina meal has acted as a strong feeding attractant for Litopenaeus vannamei at a very low dietary inclusion level. Aquaculture Research, 43, 430-437. 
https://doi.org/10.1111/j.1365-2109.2011.02846.x

Sirakov, I., Velichkova, K., Nikolov, G. (2012). The effect of algae meal (Spirulina) on the growth performance and carcass parameters of rainbow trout (Oncorhynchus mykiss) J. Journal of Bioscience and Biotechnology, Special Edition, 151-156.

Spranghers, T., Ottoboni, M., Klootwijk C., Ovyn, A., Deboosere, S., De Meulenaer, B., Michiels J., Eeckhout, M., De Clercq, P., De Smet, S. (2017). Nutritional composition of black soldier fly (Hermetia illucens) prepupae reared on different organic waste substrates. Journal of the Science of Food and Agriculture, 97(8), 2594-2600.

https://doi.org/10.1002/jsfa.8081

Tacon, A.G.J., Hasan, M.R., Subasinghe, R.P. (2006). Use of fishery resources as feed inputs to aquaculture development: Trends and policy implications. Rome, Italy: FAO Fisheries Circular No. 1018, FAO Fisheries Department; Food and Agriculture Organization of the United Nations.

Teimouri, M., Amirkolaie, A.K., Yeganeh, S. (2013). The effects of Spirulina platensis meal as a feed supplement on growth performance and pigmentation of rainbow trout (Oncorhynchus mykiss). Aquaculture, 396-399, 14-19.

https://doi.org/10.1016/j.aquaculture.2013.02.009

Ungsethaphand, T., Peerapornpisal, Y., Whangchai, N., Sardsud, U. (2010). Effect of feeding Spirulina platensis on growth and carcass composition of hybrid red tilapia (Oreochromis mossambicus X O. niloticus). Maejo International Journal of Science and Technology, 4, 331-336.
Velasquez, S.F., Chan, M.A., Abisado, R.G., Traifalgar, R.F.M., Tayamen, M.M., Maliwat, G.C.F., Ragaza, J.A. (2016). Dietary Spirulina (Arthrospira platensis) replacement enhances performance of juvenile Nile tilapia (Oreochromis niloticus) Journal of Applied Phycology, 28(2), 1023-1030.

https://doi.org/10.1007/s10811-015-0661-y

Vizcaino, A., Lopez, G., Saez, M., Jimenez, J., Barros, A., Hidalgo, L., Camacho-Rodriguez, J., Martinez, T., Ceron- Garcia, M., Alarcion, F. (2014). Effects of the microalgae Scenedesmus almeriensis as fishmeal alternative in diets for gilthead sea bream, Sparus aurata, juveniles. Aquaculture, 431, 34-43.

https://doi.org/10.1016/j.aquaculture.2014.05.010

Wang, L., Li, J., Jin, J., Zhu, F., Roffeis, M., Zhang, X. (2017). A comprehensive evaluation of replacing fishmeal with housefly (Musca domestica) maggot meal in the diet of Nile tilapia (Oreochromis niloticus): Growth performance, flesh quality, innate immunity and water environment. Aquaculture Nutrition, 23(5), 983-993.

https://doi.org/10.1111/anu.12466

Webster, C.D., Tiu, L.G., Tidwell, J.H. (1997). Effects of replacing fish meal in diets on growth and body composition of palmetto bass (Morone saxatilis $\times M$. chrysops) raised in cages. Journal of Applied Aquaculture, 7, 53-67.

https://doi.org/10.1300/J028v07n01_05

Yeganeh, S., Teimouri, M., Amirkolaie, A.K. (2015). Dietary effects of Spirulina platensis on hematological and serum biochemical parameters of rainbow trout (Oncorhynchus mykiss). Research in Veterinary Science, 101, 84-88.

https://doi.org/10.1016/i.rvsc.2015.06.002 